\title{
Scedosporium apiospermum EUMYCETOMA SUCCESSFULLY TREATED WITH ORAL VORICONAZOLE: REPORT OF A CASE AND REVIEW OF THE BRAZILIAN REPORTS ON SCEDOSPORIOSIS
}

Flávio de Mattos OLIVEIRA(1,2), Gisela UNIS(3,4), Bruno HOCHHEGGER(5) \& Luiz Carlos SEVERO(2,6,7)

\begin{abstract}
SUMMARY
We describe a case of white-grain eumycetoma caused by Scedosporium apiospermum in an immunocompetent host that was successfully treated with oral voriconazole, and we review the Brazilian reports on scedosporiosis.
\end{abstract}

KEYWORDS: Scedosporium apiospermum; Pseudallescheria boydii; Scedosporiosis; Eumycetoma, Voriconazole.

\section{INTRODUCTION}

The asexual state of the ascomycete Scedosporium apiospermum (previously known as Monosporium apiospermum) and its sexual state, Pseudallescheria apiosperma (previously Allescheria boydii, Petriellidium boydii and Pseudallescheria boydii), are ubiquitous saprobic fungi commonly found in temperate climates, and have been recovered from water, sewage, soil, swamps, and manure ${ }^{2,4}$. Both sexual forms are frequently seen in human infections (scedosporiosis), both as the cause of systemic disease in immunocompromised patients and eumycetoma in immunocompetent patients ${ }^{2}$.

Eumycetoma is a chronic progressive granulomatous infection of the subcutaneous tissue. It may affect muscles, bones, cartilage and joints, most often affecting the lower extremities, usually the foot. The disease is caused by either fungi or bacteria, giving rise to eumycetomas and actinomycetomas, respectively. It has a classic triad of soft tissue swelling, draining sinus tracts, and extrusion of grains. The term mycetoma can also be found in literature incorrectly referring to a fungus ball ${ }^{21}$.

We describe a case of white-grain eumycetoma caused by $S$. apiospermum in an immunocompetent host that was successfully treated with oral voriconazole, and we review the Brazilian reports on scedosporiosis.

\section{CLINICAL CASE}

A 58-year-old woman from rural southern Brazil presented with a 1-year history of progressive pain and swelling of the left foot. She had injured her foot before while handling a milch cow. Physical examination revealed a tumor-like process of the foot that had several draining sinus tracts (Fig. 1). Foot plain radiography showed widening of joint spaces, periostial reaction, bone destruction, erosive changes and demineralization (Fig. 2). An incisional skin biopsy was taken from the foot over opening draining sinuses. Haematoxilin and eosin stain demonstrated a granulomatous response on the dermis and subcutaneous tissue containing localized abscesses with spherical white-grain eumycetoma. Culture of a sample of the biopsy on Sabouraud glucose agar revealed fungal growth identified as S. apiospermum.

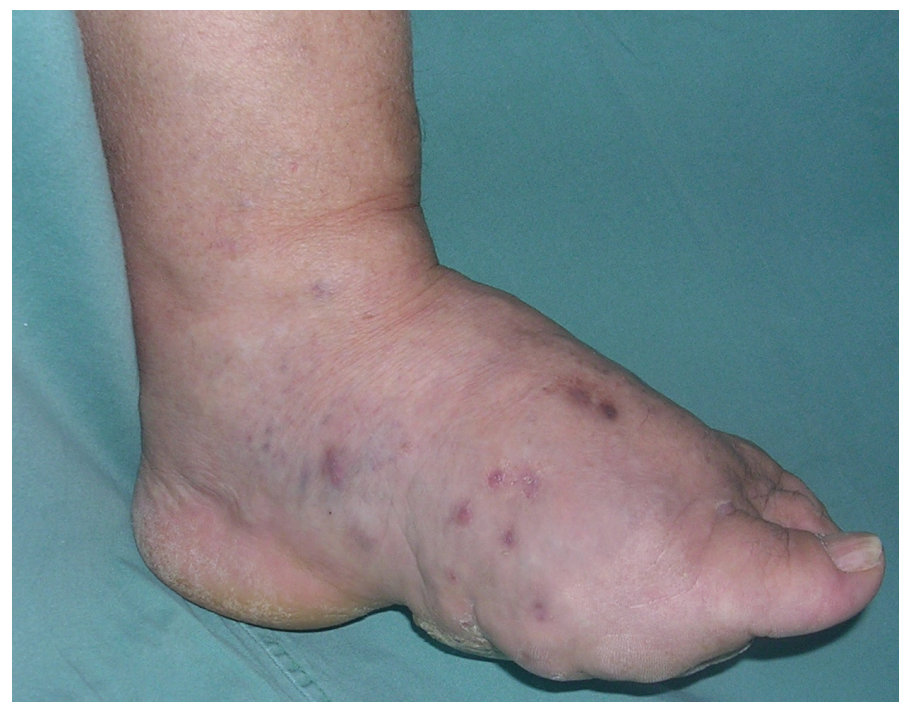

Fig. 1 - Swelling at the left foot that discharge grains through sinus tracts.

(1) Doutor em Ciências Pneumológicas, Universidade Federal do Rio Grande do Sul (UFRGS), Brazil.

(2) Laboratório de Micologia, Hospital Santa Rita, Irmandade Santa Casa de Misericórdia de Porto Alegre, RS, Brazil.

(3) Doutora em Pneumologia, UFRGS.

(4) Hospital Sanatório Partenon, Porto Alegre, RS, Brazil.

(5) Professor Adjunto de Radiologia, Universidade Federal de Ciências da Saúde de Porto Alegre, Rio Grande do Sul, Brazil.

(6) Departamento de Medicina Interna, Faculdade de Medicina, UFRGS.

(7) Pesquisador 1B CNPq.

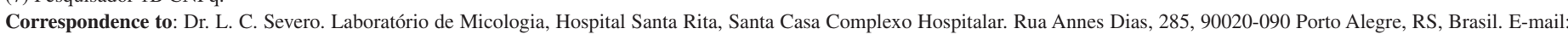
severo@santacasa.tche.br; severo@pesquisador.cnpq.br 


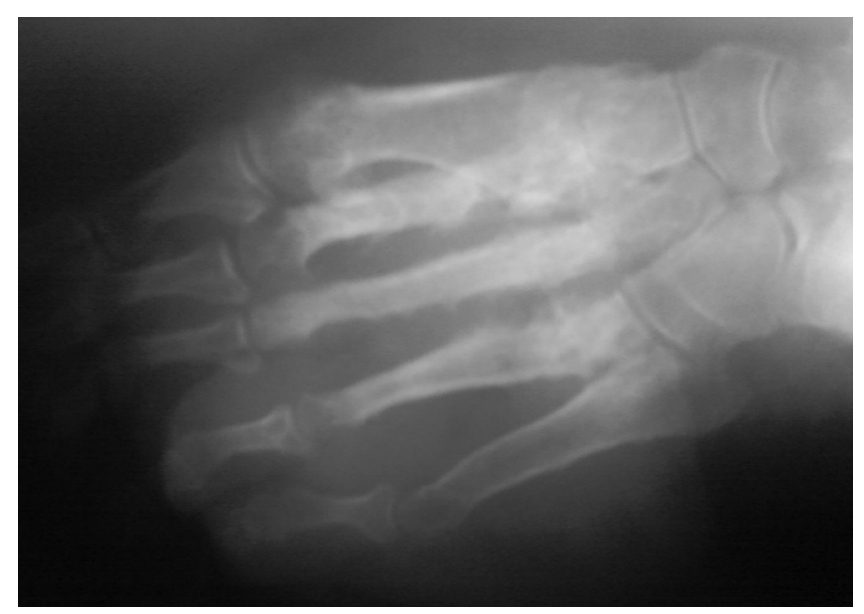

Fig. 2 - Standard X-ray shows a swelling of the soft tissue periosteal reaction and osteolytic lesions.

Treatment and evolution. She failed to respond to itraconazole (200 $\mathrm{mg} /$ day) in two years of regular use of the drug, and the disease showed clinical evidence of progression. The patient refused surgical resection of the limb. Therapy with oral voriconazole at a dose of $200 \mathrm{mg}$ twice per day was initiated, showing clinical improvement and good tolerance. At follow-up, three years later, her clinical signs had been completely resolved and foot plain radiography demonstrated partial regression of periostial reaction and bone sclerosis that suggested response to treatment (Fig. 3).

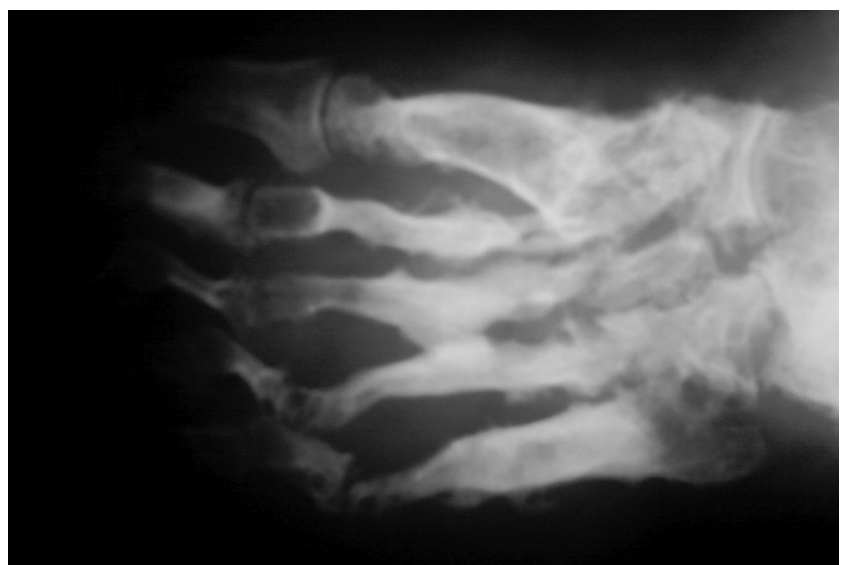

Fig. 3 - Foot plain radiography demonstrating partial regression of periosteal reaction and bone sclerosis three years after voriconazole treatment.

Table 1

Demographic characteristics, clinical data, diagnosis, treatment, and outcome for 15 patients with scedosporiosis in Brazil from 1982

\begin{tabular}{|c|c|c|c|c|c|}
\hline $\begin{array}{l}\text { Case } \\
\text { (Ref.) } \\
\end{array}$ & Age/Gender & Diagnostic specimen & Associated diseases & Type of infection & Treatment/Outcome \\
\hline $\begin{array}{l}1 \\
(17) \\
\end{array}$ & $65 / \mathrm{M}$ & Lung tissue & Active tuberculosis & Lung fungus ball & $\begin{array}{l}\text { None/ } \\
\text { Death }\end{array}$ \\
\hline $\begin{array}{l}2 \\
(3)\end{array}$ & $38 / \mathrm{M}$ & Soft tissue & None & Mycetoma-like infection & $\begin{array}{l}\text { None/ } \\
\text { Improved }\end{array}$ \\
\hline $\begin{array}{l}3 \\
(8) \\
\end{array}$ & Not done & Lung and brain tissue & Leukemia & Brain and lung abcesses & $\begin{array}{l}\text { None/ } \\
\text { Death }\end{array}$ \\
\hline $\begin{array}{l}4 \\
(9) \\
\end{array}$ & $45 / \mathrm{M}$ & Soft tissue & $\begin{array}{l}\text { Diabetes and renal } \\
\text { transplant recipient }\end{array}$ & Subcutaneous nodule & $\begin{array}{l}\text { Surgical resection and } \\
\text { Itraconazole/Cure }\end{array}$ \\
\hline $\begin{array}{l}5 \\
6 \\
(18)\end{array}$ & $\begin{array}{l}73 / \mathrm{F} \\
66 / \mathrm{F}\end{array}$ & $\begin{array}{l}\text { Soft tissue } \\
\text { Soft tissue }\end{array}$ & $\begin{array}{l}\text { Breast carcinoma } \\
\text { None }\end{array}$ & $\begin{array}{l}\text { Subcutaneous ulcerated lesion } \\
\text { Subcutaneous nodule }\end{array}$ & $\begin{array}{l}\text { None/death } \\
\text { Itraconazole/Cure }\end{array}$ \\
\hline $\begin{array}{l}7 \\
(11) \\
\end{array}$ & $40 / \mathrm{M}$ & Maxillary sinus tissue & $\begin{array}{l}\text { Bone marrow } \\
\text { transplantation }\end{array}$ & Sinusitis & $\begin{array}{l}\text { Amphotericin B, itraconazole/ } \\
\text { Death }\end{array}$ \\
\hline $\begin{array}{l}8 \\
(19) \\
\end{array}$ & $41 / \mathrm{F}$ & Lung tissue & $\begin{array}{l}\text { Cured tuberculosis, } \\
\text { Diabetes }\end{array}$ & Lung fungus ball & Ketoconazole/Death \\
\hline $\begin{array}{l}9 \\
(20) \\
\end{array}$ & $12 / \mathrm{M}$ & Peritoneal effusion & End stage renal disease & Peritonitis & None/Improved \\
\hline $\begin{array}{l}10 \\
11 \\
12 \\
13 \\
(21) \\
\end{array}$ & $\begin{array}{l}45 / \mathrm{M} \\
36 / \mathrm{F} \\
57 / \mathrm{F} \\
66 / \mathrm{M}\end{array}$ & $\begin{array}{l}\text { Lung tissue } \\
\text { Lung tissue } \\
\text { Lung tissue } \\
\text { Maxillary sinus tissue }\end{array}$ & $\begin{array}{l}\text { Cured tuberculosis } \\
\text { diabetes } \\
\text { Cured tuberculosis } \\
\text { None }\end{array}$ & $\begin{array}{l}\text { Lung fungus ball } \\
\text { Lung fungus ball } \\
\text { Lung fungus ball } \\
\text { Maxillary sinus fungus ball }\end{array}$ & $\begin{array}{l}\text { Surgery/Cure } \\
\text { Surgery/Cure } \\
\text { Surgery/Cure } \\
\text { Surgery/Cure }\end{array}$ \\
\hline $\begin{array}{l}14 \\
(5) \\
\end{array}$ & $32 / \mathrm{M}$ & Spinal fluid & Near drowning & Central nervous system & $\begin{array}{l}\text { Fluconazole, amphotericin B/ } \\
\text { Death }\end{array}$ \\
\hline$\overline{15}$ & $58 / \mathrm{F}$ & Soft tissue & None & Eumycetoma & $\begin{array}{l}\text { Itraconazole, } \\
\text { Voriconazole/Cure }\end{array}$ \\
\hline
\end{tabular}




\section{DISCUSSION}

S. apiospermum causes infections in both immunocompetent and immunosuppressed individuals. This fungus is commonly associated with eumycetoma but infections in other sites have continued to be reported and consequently their clinical spectrum has been considerably enlarged ${ }^{4}$.

Scedosporiosis is reported infrequently. In Brazil, twenty-four cases of the infection were found described in the available literature. MAGALHÃES ${ }^{12}(\mathrm{RJ})$ and LINHARES ${ }^{7}$ (RJ) each described separately the first case of S. apiospermum infection in 1916 and 1917. In 1980, ROCHA et al. ${ }^{16}$ reported one case of eumycetoma and reviewed the nine similar previous cases and PURCHIO et al. ${ }^{14}$ reported another case of eumycetoma. All cases reported before 1982 were from subcutaneous infection of immunocompetent hosts which presented as eumycetoma. Table 1 is up to date with the Brazilian literature on scedosporiosis. As shown in the table, the most frequent clinical manifestation of scedosporiosis was fungus ball, especially from cured pulmonary tuberculosis patients (Cases 8,10,12). The second clinical presentation was localized invasive infection from immunosuppressed patients (Cases $3,5,7)$. For the first time a central nervous system infection, secondary to near drowning, is reported in Brazil (Case 14).

Before the development of new drugs ${ }^{2}$ more effective against $S$. apiospermum, the most successful approach to the control of eumycetoma was surgical, usually amputation ${ }^{15}$. The correct diagnosis of white-grain eumycetoma is important because $S$. apiospermum is resistant to a variety of commonly used antimycotic agents. To our knowledge, this is the second case of $S$. apiospermum eumycetoma successfully treated with voriconazole $^{13}$. This drug has been used in a few cases of eumycetoma ${ }^{1,6,10}$, and although expensive it should be considered a first-line antifungal agent for the treatment of eumycetoma caused by S. apiospermum. The dose required and the duration of the course for optimum therapy should be investigated.

\section{RESUMO}

\section{Eumicetoma por Scedosporium apiospermum tratado com sucesso com voriconazol oral: relato de um caso e revisão da literatura brasileira sobre scedosporiose}

Relatamos um caso de eumicetoma por grão branco causado por Scedosporium apiospermum em um hospedeiro imunocompetente que foi tratado com voriconazol oral e revisamos a literatura brasileira sobre scedosporiose.

\section{REFERENCES}

1. Ameen M, Arenas R. Developments in the management of mycetomas. Clin Exp Dermatol. 2009;34:1-7.

2. Cortez KJ, Roilides E, Queiroz-Telles F, Meletiadis J, Antachopoulos C, Knudsen T, et al. Infections caused by Scedosporium spp. Clin Microbiol Rev. 2008;21:157-97.

3. Heins-Vaccari E, Lacaz CS, Rodrigues EG. Forma de micetomatóide de infecção humana por Scedosporium apiospermum. An bras Dermatol. 1990;65:193-5.

4. Kantarcioglu AS, de Hoog GS, Guarro J. Clinical characteristics and epidemiology of pulmonary pseudallescheriasis. Rev Iberoam Micol. 2012;29:1-13.
5. Kowacs PA, Soares Silvado CE, Monteiro de Almeida S, Ramos M, Abrão K, Madaloso LE, et al. Infection of the CNS by Scedosporium apiospermum after near drowning. Report of a fatal case and analysis of its confounding factors. J Clin Pathol. 2004;57:205-7.

6. Lacroix C, de Kerviler E, Morel P, Derouin F, Feuilhade de Chavin M. Madurella mycetomatis mycetoma treated successfully with oral voriconazole. Br J Dermatol. 2005; $152: 1067-8$

7. Linhares DV. Sobre um caso de clínica cirúrgica (Mycetoma podal). [Tese]. Rio de Janeiro; Faculdade Nacional de Medicina; 1917.

8. Londero AT, Pereira DV. O pulmão nas micoses oportunísticas sistêmicas. Arq bras Med. 1990;64:291-5.

9. Lopes JO, Alves SH, Benevenga JP, Salla A, Khmohan C, Silva CB. Subcutaneous pseudallescheriasis in a renal transplant recipient. Mycopathologia. 1994;125:153-6.

10. Loulergue P, Hot A, Dannaoui E, Dallot A, Poirée S, Dupont B, Lortholary O. Successful treatment of black-grain mycetoma with voriconazole. Am J Trop Med Hyg. 2006:75:1106-7.

11. Machado CM, Martins MA, Heins-Vaccari EM, Lacaz CS, Macedo MC, Castelli JB, et al. Scedosporium apiospermum sinusitis after bone marrow transplantation: report of a case. Rev Inst Med Trop Sao Paulo. 1998;40:321-3.

12. Magalhaes PS. Um caso de micetoma podal de grãos branco-amarelados. An Policlin Geral (Rio). 1916;3:151-8

13. Porte L, Khatibi S, Hajj LE, Cassaing S, Berry A, Massip P, et al. Scedosporium apiospermum mycetoma with bone involvement successfully treated with voriconazole. Trans R Soc Trop Med Hyg. 2006;100:891-4.

14. Purchio A, Gambale W, Paula CR, Yamamura I, Cavalcante ASB. Micetoma do antebraço por Petriellidium boydii. Registro de um caso. An bras Dermatol. $1981 ; 56: 281-4$

15. Rippon JW. Pseudallescheriasis. In: Rippon JW, editor. Medical Mycology: the pathogenic fungi and the pathogenic actinomycetes. $3^{\text {rd }}$ ed. Philadelphia: Saunders; 1988. p. $651-80$

16. Rocha OM, Lacaz CS, Porto E, Heins E, Schaf S, Hirose-Pastor E, et al. Micetoma articular por Petriellidium boydii: registro de um caso. Rev Inst Med Trop Sao Paulo. 1980:22:24-9

17. Severo LC, Londero AT, Picon PD, Rizzon CFC, Tarasconi JC. Petriellidium boydii fungus ball in a patient with active tuberculosis. Mycopathologia. 1982;77:15-7.

18. Severo LC, Oliveira FM, Londero AT. Subcutaneous scedosporiosis. Report of two cases and review of the literature. Rev Inst Med Trop Sao Paulo. 1997;39:227-30.

19. Severo LC, Porto NS, Londero AT. Pulmonary scedosporiosis. Rev Inst Med trop Sao Paulo. 1998;40:241-3.

20. Severo LC, Oliveira FM, Garcia CD, Uhlmann A, Londero AT. Peritonitis by Scedosporium apiospermum in patient undergoing continuous ambulatory peritoneal dialysis. Rev Inst Med Trop Sao Paulo. 1999;41:263-4.

21. Severo LC, Oliveira FM, Irion K. Respiratory tract intracavitary colonization due to Scedosporium apiospermum. Report of four cases. Rev Inst Med Trop Sao Paulo. 2004:46:43-6.

Received: 6 July 2012

Accepted: 28 August 2012 